\title{
Short Delay Free Recall
}

National Cancer Institute

\section{Source}

National Cancer Institute. Short Delay Free Recall. NCI Thesaurus. Code C120405.

A part of the California Verbal Learning Test, second edition. Following a delay, the subject is asked to recall words, without an additional presentation of those words. 